\title{
A Study on the Current and Future Impacts of the Political System on Kerala's Tourism Sector
}

Sandhyta $\mathrm{H}^{*}$ and Bindi Varghese ${ }^{\dagger}$

\begin{abstract}
Tourism is one of the predominant sectors of the economy of Kerala. Tourism in Kerala attracts millions of foreign and domestic visitors and garners revenue that totals to around 20,000 crores. Generating over a million employment opportunities and supporting the skilled and non-skilled labour equally, the tourism and hospitality industry is an inevitable part of the economy. Kerala is a preferred destination for its luxurious Ayurveda spas, backwater resorts, exquisite home stays, hill top bungalows and beach properties. Despite the commendable service and good performance of the hospitality industry, frequent civil disturbances have been identified as a major threat to the tourism industry. The State experiences hartals almost every fortnight resulting in businesses to shut down and offices and other undertakings forced to cease their operations causing huge losses to the economy. The "dawns to dusk hartals" are very common in Kerala during which the residents and the local population suffer as there is an unavailability of transportation, retail shops to buy the basic necessities, lack of public facilities like banks etc. Many tourists get stranded in airports, railway stations and bus stops as there are no transportation facilities available for reaching their destination. This paper
\end{abstract}

* St. Michels College, Chertala, Kerala, India; mail id

† Christ University, Bengaluru, India, bindi.varghese@christuniversity.in 
attempts to study the impact of civil disturbances on the functioning of the tourism industry in Kerala.

Keywords: Civil Disturbances, Destination Image, Destination Branding and Marketing

\section{Introduction}

Tourism is a fast growing industry with multiple benefits to an economy. Tourism, from the ancient times has fascinated mankind and is now perceived as an integral part in the modern day (Bhatia, 2002). The tourism phenomenon has attracted almost the entire world. With the advent of technology, speedy development in means of transport and communication has made distant places on this earth practically accessible to wider segments of the population around the globe. It provides an opportunity to millions to enjoy the prospect from moving from one continent to another in a matter of hours. Along with industrialization and modernization, tourism industry has also grown rapidly throughout the world. Since mid-60's international tourism has become the number one item of international trade. Many countries and destinations started competing among each other to emerge successful in the global market.

\section{Tourism and Hospitality Sector in Kerala}

Kerala, a State situated on the tropical Malabar Coast of southwestern India is one of the most popular tourist destinations in the country. Named as one among the ten paradises of the world by National Geographic Traveller, Kerala is famous especially for its ecotourism initiatives and beautiful backwaters (WTTC, 2008). Its unique culture and traditions, coupled with its varied demography, have made Kerala one of the most popular tourist destinations in the world.

Until the early 1980s, Kerala was a relatively unknown destination. Aggressive marketing campaigns launched by the Kerala Tourism Development Corporation (KTDC) - the government agency that oversees tourism prospects of the State laid the foundation for the growth of the tourism industry. In the decades that followed, Kerala Tourism could transform itself into one of the niche holiday 
destinations in India. The tag line Kerala - "God's Own Country" was adopted in its tourism promotions and became a global brand. Kerala is regarded as one of the destinations with the highest brand recall. In 2010, Kerala attracted 6,60,000 foreign tourist arrivals as per the tourism statistics of the State (Kerala Tourism Policy, 2015, pp.7).

The State's tourism agenda promotes ecologically sustained tourism, which focuses on the local culture, wilderness adventures, volunteering and personal growth of the local population. Efforts are taken to minimise the adverse effects of traditional tourism on the natural environment, and enhance the cultural integrity of local people.

The State offers a diverse mix of tourism products including heritage, culture, traditions, adventure and serene and beautiful nature. The most unique feature of the destination is that unlike other destinations like for instance Rajasthan, which promotes the various destinations within the State (Jaipur, Udaipur etc.), the whole State itself is a tourism product (Vasudevan, 2007). Kerala gets a large share in the Indian market due to its competitiveness and unique brand image.

According to WTTC report (2000), Kerala was the first Indian State to become a partner in the World Travel and Tourism Council. Also, it attracts around 5.8 million tourists every year.

Therefore, Kerala as a brand has positioned itself in a very competent and unique manner. Tourists flock into the State throughout the year as the State has been recently declared as a "Year around Destination" (NDTV Tourism Destinations Report, 2008). The monsoon season is promoted as the "dream season" as the State experiences heavy rainfall during this period (The Hindu, 2010). The State also attracts a lot of foreigners who desire to indulge in ayurvedic massages and medicinal baths. Kerala's cuisine is also much popular among the foreign tourists due to its unique blend of spices and distinctive taste. Yet another attraction of the State is the festivals and fairs at the destination like Onam; the harvest festival of Kerala, Snake Boat Race, Trissur poorametc which attracts thousands of tourists to experience these cultural extravaganza (http:/ / www.keralatourism.org/). 
The State also has an amazing history to share depicting many palaces, old and heritage structures, temples, churches, mosques, forts and many more. The unspoiled coastline offering pristine beaches pulls many tourists to the State to enjoy the sun, sea and sand. The art and dance forms are another tourist attraction of Kerala. The very famous Ravi Varma paintings are a classic example of the same. Kerala's dance forms and music are also promoted and marketed effectively. This includes mohiniyattam, kadhakali, theyyam, koodiyattam, ottanthullal etc. Koodiyattam is the only intangible asset from the State that has been listed in the UNESCO world heritage list (UNESCO Heritage Listing, 2009).

Promoted by the Kerala Tourism Development Corporation (KTDC) with the tagline "Gods Own Country" Kerala has emerged as an innovative and unique brand. KTDC is a public sector venture with its headquarters in the capital city, Thiruvananthapuram or Trivandrum and has branches all across the State. They effectively manage the tourism industry at the destination by coordinating with the various key participants in the tourism system like hotels, transport services, travel agents, tour operators and the other public and private institutions supporting tourism.

Formed in 1960 by the government of Kerala, KTDC became a separate commercial entity in 1970. The major objectives behind such a venture was to promote Kerala as a leading tourist destination by providing high quality hospitality services to the tourists, provide adequate information to interested parties and to ensure optimum return on investment to the government on the investment projects (Kerala Tourism Policy, 2015). This undertaking has been one of the most profitable ventures by the government of Kerala. KTDC manages the hotels, motels, resorts and other accommodation facilities at the state. They have effectively categorized the hotels and resorts into premium, value and budget category to cater to the needs of the various tourists (pp.11).

Kerala is a State highly influenced by politics and the political system is very rigid and structured. The State has various civic parties playing a dominant role in the functioning of the society. The political instability of the State affects the economy and the 
businesses that exist within the State. The state experiences hartals and strikes almost every fortnight resulting in businesses to shut down and offices and other undertakings forced to cease their operations resulting in huge losses to the economy. The "dawns to dusk hartals" are very common in Kerala during which the residents and the local population suffer due to the unavailability of transportation, retail shops to buy the basic necessities, lack of public facilities like banks etc. Many people get stranded in airports, railway stations and bus stops as there are no transportation facilities available for reaching their destination.

\section{Literature review}

Roy and Borsha (2013) specify hartals as "a violent challenge to the socio-economic development of Bangladesh. The study focuses on how hartals affect the economy as a whole and the various businesses operating within the economy. This includes tourism, agriculture, transportation and other small businesses. The study was done using secondary data from various journals, websites and newspaper articles. The author gives suggestions and measures to minimize the impacts of hartals and draws an effective model for the economy and the impact of hartals on every sector. The article concludes by projecting a strong message that "hartals are useless and are just a tool used by the political parties in the opposition before elections for their electoral success". Naik (2013), through his study on the opportunities and challenges in promoting Kannur district of Kerala as a competent tourist destination, explains the major factors that affect a destination and its competitiveness. The study uses both primary and secondary data. Primary data was collected by distributing questionnaires to the tourists and the secondary data was collected from journals, magazines and newspaper articles. The study focuses on the major elements of destination competitiveness like the infrastructure, human resource availability, service quality, marketing and promotion, safety and security and the regulatory issues.

The major findings of the study were that political system of the destination, accommodation, accessibility and lack of manpower and skilled labour has highly affected the tourist inflow to the destination. The author also suggests ways and measures to 
improve the system by providing more services to the tourists while reducing or controlling the political disturbances and frequent hartals at the destination. The study examines the need for better marketing and promotion of the destination to attract more tourists and thereby develop the economy. Similarly, Ahmed and Jahan (2013) examined the prospects of rural tourism in Bangladesh and the socio-cultural, economic and environmental impacts of tourism in the destination. Through a qualitative analysis by collecting secondary data from various publications and articles, the major challenges faced by the country was reflected upon which includes improper infrastructure, lack of awareness among the local population, lack of proper maintenance of resources, lack of safety and security in the destination due to the unstable government and the frequent political disturbances. The author points out the inefficiency of the government in improving the image of the country to develop as a competent tourism destination. On the other hand, Nasser (2012) in his study on political unrest affecting tourism in Egypt explains the impact of the Egyptian revolution due to cancelling of fleets, cancelled bookings for the travel agents and tour operators, public outrage and violence, cease of business of hotels and restaurants. The paper focuses on the tourism industry of the country. The study uses ethnographic research methodology which is an in depth research methodological approach involving field work, observation and note taking. Egypt, a destination primarily dependant on tourism industry for its income, was largely affected due to the political disturbances.

Many foreign tourists were stranded in the airports for hours with no food and water. Though the government made attempts to restore and control the situation, their attempts were in vain. There was a huge loss on the measures undertaken during the post crisis to bring the economy back to its normal shape which included a PPP model for managing and marketing the destination. The author concludes by stating that although destinations may experience political crisis and disturbances, it is very important for the government and the private and local bodies to coordinate so that the destination can be restored to regain its lost competency and appeal. As cited by Nasser (2012) in his study on Political unrest in Egypt affecting tourism, "Tourists are very sensitive to 
reports of violence and political unrest in potential holiday destinations (Neumayer, 2004)".

Venugopal (2003) examined the various global dimensions of the political unrest and civil war in Sri Lanka. The country has been experiencing political instability and a series of riots and disturbances since 1970s due to the influence of the various political parties existing in the country. The unstable political system affected the growth and development of the various industries and businesses that were operating within the system. Agriculture, trade and exports and other small scale businesses were the major income for the country. The country then restored its economy in the later years after the decline of the war in the early 2000s gained fair trade relations and international relations with many countries thereby strengthening and rebuilding its economy. Tasci (2006) points out the various factors that affect the brand image of a tourist destination and can impair the tourism business in the long run. Negative image formation happens much faster than the positive image formation (pp. 29).Dealing with the negative reputation of a destination is rather challenging for the destination marketers (Deller C S, Tsai H, Marcouller, English B, 2000). Negative stories like war, terrorism, political instability, crime and violence, breakout of diseases and calamities tend to spread faster and also create a long lasting impression about the destination. Studies have also proven that acts of terrorism or violence or other forms of security breaches also affects the neighbouring countries as the tourists also try to avoid them and choose other destinations that they perceive to be safer and secure (Hendricks, D. A, 2009).

The reviews give a clear picture of the various political systems and their impact on a destination and its competitiveness.

\section{Methodology of Research}

This research was undertaken to analyse the various impacts of political and civil disturbances on tourism and the economy of a destination. The study aims to apply quantitative method of data collection.

Quantitative research involves structured questionnaires and involves a large number of samples. Quantitative studies are 
generally categorised into two types; descriptive studies and experimental studies. While descriptive study aims to describe the relationship between the variables, experimental study is essentially to experiment the likely outcome of a particular event or a phenomenon.

Statistical Package for social sciences (SPSS) was developed by IBM for easier and simpler statistical analysis. Some of the statistical tools those are available in SPSS include descriptive statistics: Cross tabulation, Frequencies, Descriptives, Bivariate statistics: Means, t-test, ANOVA, Correlation (bivariate, partial, distances), Nonparametric tests, Linear regression for predication of numerical outcomes and tests for classifying or grouping variables; Factor analysis, cluster analysis (two-step, K-means, hierarchical), Discriminant analysis.

For the present research, primary data was collected using questionnaires. The sample for primary data included the public and private players in the tourism industry. The secondary data sources were journals, newspaper articles, websites and online travel blogs, case studies, previously undertaken research thesis etc.

A questionnaire was developed and validated by experts. A pilot study was conducted with 30 samples to assess reliability. The reliability test was performed with the help of SPSS software and the Cronbach's Alpha value was 0.861 which validates the accuracy and reliability of the data. The sampling method used for the study was convenient sampling. 100 questionnaires were distributed among the prominent travel agencies operating in Kerala. The respondents were asked to give their agreement and disagreement on the various factors associated with the functioning of tourism industry of the state on a five point Likert scale.

\section{Data analysis and interpretation}

The quantitative data analysis for the study was undertaken with the help of Statistical Protocol for Social Sciences software. This research analysis software is very effective in logical analysis of categorized and uncategorized data by performing various statistical analysis tests like Correlation, linear regression, factor analysis, cluster analysis and many other similar ways of assessing 
the data available thereby, presenting the data in a very simple and understandable manner.

The following hypothesis has been developed from the objectives of the study to understand the impact of civil disturbances on the day to day working of the members of the travel trade.

1. H0 - Hartals and strikes do not have a direct impact on the cost of business.

\section{One-Sample Statistics}

\begin{tabular}{lllll}
\hline & $\mathrm{N}$ & Mean & $\begin{array}{c}\text { Std. } \\
\text { Deviation }\end{array}$ & $\begin{array}{c}\text { Std. } \\
\text { Error Mean }\end{array}$ \\
\hline $\begin{array}{l}\text { civil disturbances and strikes affect } \\
\text { the cost of business }\end{array}$ & 91 & 4.40 & .681 & .071 \\
\hline
\end{tabular}

\section{One-Sample Test}

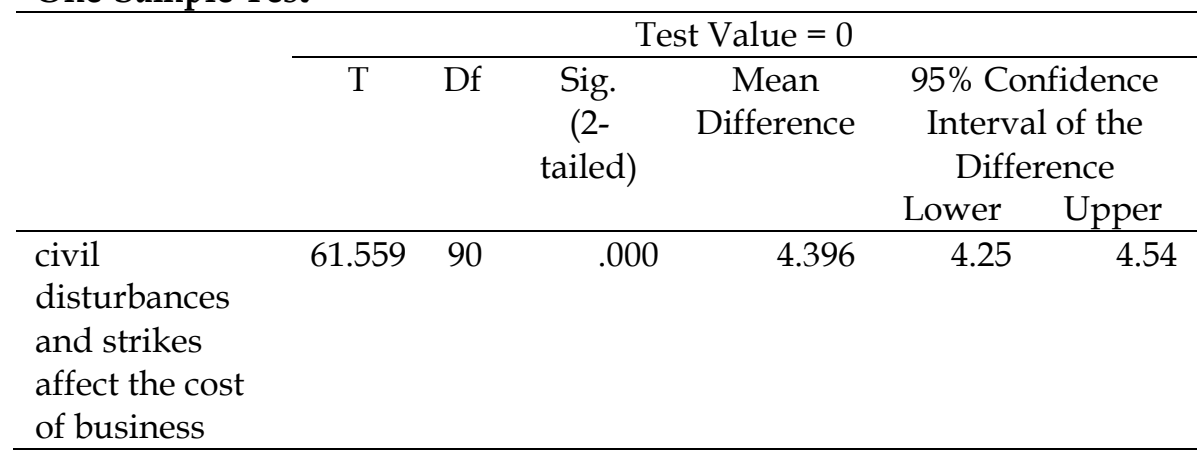

\section{Tab 4.5.5.a one sample $t$ test result}

\section{Inference}

A one sample $t$ test was performed to assess the impact of hartals and civil disturbances on the cost of day to day business. The mean value was 4.40 and standard deviation 0.681 and the test was significant at $5 \%$ confidence level with $\mathrm{P}$ value $0.000(<0.005)$. Hence, the null hypothesis is rejected.

2. H0 - Hartals and civil disturbances do not adversely affect tourism activities and earnings from tourism in the state. 


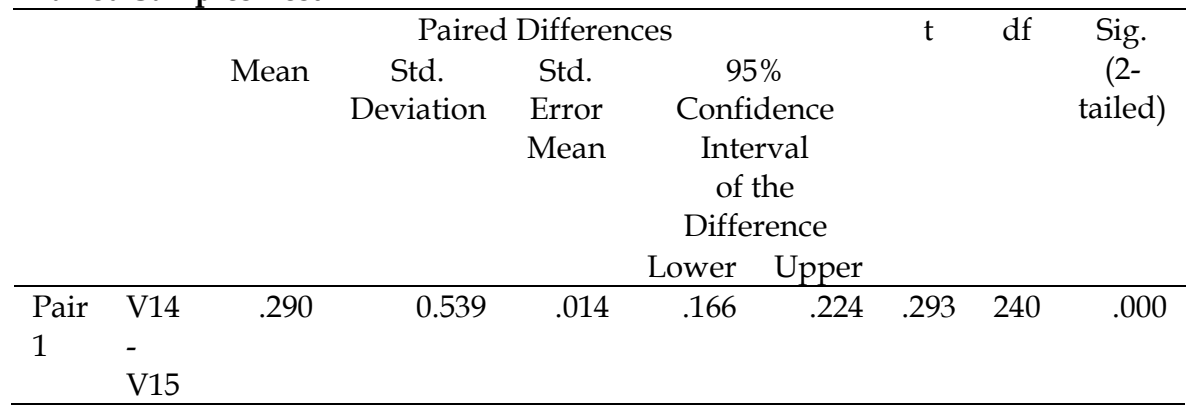

\section{Tab 4.5.6 a paired sample $t$ test results}

\section{Inference}

A paired sample $t$ test was performed to analyse the impact of hartals and civil disturbances on the tourism activities and tourism earnings. Tourism earnings before and after frequent hartals were compared and the test is significant at $5 \%$ confidence level with $\mathrm{P}$ value $0.000(<0.005)$ and therefore the null hypothesis is rejected.

\section{Major findings and suggestions}

Literature substantiates that civil disturbances of the state has an impact on the overall socio economic development of the state. In the year 2014-15, there were more than a 100 hartals and shut downs which has resulted a loss of about 90 crores to the state (The Hindu, 2015). The most affected sectors were Tourism and hospitality, IT, telecommunications and transportation. Recently, the Kerala chapter of the Confederation of Indian Industry (CII) said "a single day's shutdown costs the state a staggering 7 billion (or 700 crore) rupees" (Kerala CII report, 2015).

It was observed that the local residents at the destination, specially the younger generation are against the concept of hartals and they do not support strikes. There are campaigns and awareness programs conducted among the youth against frequent hartals and strikes in the state. The "say No to hartal" campaign was launched in 2012 with initiatives from the younger generation who extended support to the tourists and local residents who are stranded at the time of hartals. 
The tourists were happy and satisfied with the support extended by the hotels and resorts but were dissatisfied with the overall destination as many had to alter their travel plans or spend hours at the airport or railway stations to get transportation. The lack of public facilities at the state when a hartal is announced often leads to dissatisfaction and discomfort to the tourists. The sudden announcement of a strike (often called as "flash strikes")makes it difficult for the hotel authorities and travel agents to communicate the same to the tourists prior to their arrival at the state.

In the year 2015- 16, there were more than 35 hartals recorded in the state causing a loss of more than 2 million rupees (The Hindu, February 2016). Furthermore, the travel agents and the allied sectors to tourism have faced huge loss of resources and manpower. Therefore, efforts should be made to improve the infrastructure facilities which are essential for brand maintenance and enhance quality experience for the visitors to Kerala.

Literature substantiates that when a destination reaches a stage where tourists feel anxious towards the safety and security at the destination, the tourism starts to decline. Hence, corrective actions have to be made at the right time so that the brand image of the state does not get hampered. But the good news is that if the situation is handled well, the destination can reverse its negative image using proper promotion and marketing so that tourism can bounce back to its normal stature (Neumayer, 2004).

Therefore, developing appropriate measures to support the tourists at the time of hartals and provide them with adequate facilities like food, drinking water and other basic necessities result in optimum customer satisfaction. Informing the tourists about the strike well in advance can reduce the distress and discomfort of the tourists to a large extent and help them be prepared. Arranging transportation and accommodation for the tourists near the airports and railway stations can be helpful for the tourists who have travelled long distances to reach the destination.

\section{Conclusion}

Being a highly competent destination, such a situation can create a direct impact in the minds of the tourist who visit the destination. 
Numerous cases have been reported of tourists facing great difficulties to reach their destination as there were no facilities or services available to them and no mode of transportation to aid them. The inbound travel agents and tour operator have limited control over this situation as they are bound to follow the rules and regulations of the political system. Hence, this leads to such a situation where the tourists and the local residents suffer due to the sudden flash strikes and the sudden disrupt of political riots and violence in the state. This in turn largely affects the competency of the destination. Hence, it is highly significant to develop and practice certain relief measures to aid and support the tourists at the time of hartals and strikes in the state.Literature substantiates that when a destination reaches a stage where tourists feel anxious towards the safety and security at the destination, the tourism starts to decline. Hence, corrective actions have to be made at the right time so that the brand image of the state does not get hampered. But the good news is that if the situation is handled well, the destination can reverse its negative image using proper promotion and marketing so that tourism can bounce back to its normal stature (Neumayer, 2004).

The tourism policy of the state has proposed to exempt the tourism and hospitality, Information Technology and telecommunications sector from hartals. This if executed properly can enhance tourist satisfaction and thereby improve the destination brand.

\section{Scope for further research}

Considering the findings and limitations of the present research, there are several areas which call for further in depth research studies. The study is focussing on the impact of civil disturbances on the tourism sector of the economy. Further studies can be undertaken on the impact of hartals on various sub sectors of the economy.

\section{References}

Ahmed and Jahan (2013). Rural Tourism- Prospects in Rustic Bengal. European journal of Business Management. 5 (16). 163-172. 
Ahmed and Kader (2015). Political Benefits Outweigh Socio- economic losses: A study from Bangladesh. Public policy and Administration Research, 5(5), 81-89.

Anupama R (2013 December 13). Hartal Tourism. The Business Line Internet Edition. Retrieved from http:// www.thehindubusinessline.com/news/national/spare-tourism-fromhartals-politicians-told/article8000783.ece

ATTOI (2016. June 15) Hartals\& its implications to tourism industry. Attoi Report. pp. A 14 Retrieved from http:// www.attoi.org/ mediatalks.html

Ganga (2010 September 15). The Save Kerala Initiative- Hartal's own country. The Times of India. Retrieved from http://articles. economictimes.indiatimes.com/2013-11-24/news/44390617_1_ hartal -tourism-industry-political-parties

Ganga (2010 September 15). The Save Kerala Initiative- Hartal's own country. The Times of India. Pp. A22 Retrieved from http:// savekerala .blogspot.in/2006/09/how-hartals-and-bandhs-hijackedour.html

Gouridasan Nair (2014 March 14). The poor bear the brunt of hartals: study. The Hindu. Pp. A4. Retrieved from http:// theindependentbd .com/index.php?option $=$ com_content\&view $=$ article\&id=163782:15injured-in-hib-cops-clashes-in-ctg\&catid=187:online-edition \& Itemid $=223$

Harris C J (2015. 16 November). Gods Own Country has now become a Land of Hartals. The Indian Express. Pp. 14 Retrieved from http:/ / www.newindianexpress.com/states/kerala/RSS-Hartal-Total-Affects -Normal-Life-in-Kerala/2014/09/03/article2411518.ece

Haddad, Nasar and Ibrahim (2015) How to re-emerge as a Tourism Destination after a Period of Political Instbility. The Travel and Tourism Competitiveness Report, 53-57.

Jose (2013). Strategic Decisions and Focussed Marketing. Proceedings of 21st International Business Research Conference 10 - 11 June, 2013, Ryerson University, Toronto, Canada.

Manoj N (2015, august 24). Include tourism in proposed bill against hartals, urges KTM. The Business Line, The Hindu. Pp. A17.

India Ministry of Tourism, (2012). Results-framework document (RFD) for ministry of tourism - (2012-2013). Retrieved from website: http:// tourism.gov.in/writereaddata/Uploaded/RFD/050220121004071.pdf ("Results-framework document (rfd)," 2012)

Ministry of Tourism Government of India, (2007).Competitiveness of tourism sector in India with selected other countries of the world. Retrieved from website:http://tourism.gov.in/writereaddata/CMSPagePicture/file/ 
marketresearch/studyreports/IndiaTourismGlobal.pdf

("Competitiveness of tourism," 2007)

Ministry of Tourism Government of India, (2012). Annual report 2011-12. Retrieved from website: http://tourism.gov.in/writereaddata/ Uploaded/ Tender/051720121254577.pdf, ("Annual report 2011-12," 2012)

Ministry of Tourism Government of India, (2007). Report of the working group on tourism. Retrieved from website: http:// planning commission.nic.in/ aboutus/ committee/ wrkgrp11/ wg11 _tourism.pdf, ("Report of ," 2007)

Naik (2013). Opportunities and challenges for tourism in Kannur District of Kerala. International Journal of Applied Services Marketing Perspectives. 2(4), 632-637.

Nassar (2012). Political Unrest Costs Egyptian Tourism Dearly: An Ethnographical study. International Business Research, 5 (10), 164- 174.

Ravi Menon (2015 April 21). Tourists, travelers worst affected by hartal. The Hindu. Pp.A9. Retrieved from http://www.thehindu.com/ todays-paper/tp-national/tp-kerala/tourists-travellers-worstaffected-by-hartal/article1980259.ece

Roy and Borsha (2013). Hartal: A Violent Challenge To The SocioEconomic Development of Bangladesh. International Journal of Scientific \& Technology Research, 2(8), 86-99.

Subhash Ghosh (2009 December 24) No More Hartal in Kerala. Retrieved from http://nomorehartalinkerala.blogspot.in/2009/12/hartalsbadily-affecting-tourism.html

Sukumaran C V (2013, December 15). God's own country and Hartal's own people. The Hindu. Pp. A4. Retrieved from http:// www.thehindu.com/news/cities/Thiruvananthapuram/hartalaffects-life-in-kerala/article6994638.ece

Subramanian (2015, March 15). Hartal affects life in Kerala. The Hindu. Pp. A7. Retrieved fromhttp://www.thehindu.com/todayspaper/tp-national/tp-kerala/tourists-travellers- worst-affectedby-hartal/article1980259.ece

Sanandakumar (2013, November 24). Hartal menace in Kerala: People learn to enjoy shutdowns, but tourism industry suffers. Retrieved from http://nomorehartalinkerala.blogspot.in/ 2009/ 12/ hartalsbadily-affecting-tourism.html

Unnikrishnan S (2008, july 06). Kerala - Hartal's Own Country. The Rediff News. Retrieved from ="http:// b.scorecardresearch.com/ $\mathrm{p}$ ?c1 $=2 \& \mathrm{c} 2=6035613 \& \mathrm{cv}=2.0 \& \mathrm{cj}=1 "$ / $>$

Venugopal (2003). The Global Dimensions of Conflict in Sri Lanka. QEH Working Paper Series. pp.1-33. 
World Economic Forum (2007b), World Global Competitiveness Report, 20062007, World Economic Forum, Geneva, available at: www. weforum.org/ en/initiatives/gcp/

WTTC (2004), Competitiveness Monitor, World Travel and Tourism Council, available at: www. wttc.org/frameset3.htm 